\title{
Carbon Dynamics of Reclaimed Coal Mine Soil under Agricultural Use: A Chronosequence Study in the Dongtan Mining Area, Shandong Province, China
}

\author{
Jun-Feng $Q u^{1,2,+}$, Yu-Le Hou ${ }^{1,+}{ }^{,}$Meng-Yu Ge ${ }^{1}$, Kun Wang ${ }^{1}$, Shu Liu ${ }^{1}$, Shao-Liang Zhang ${ }^{1}$, \\ Gang $\mathrm{Li}^{1}$ and $\mathrm{Fu}$ Chen ${ }^{1,2, *}$ \\ 1 School of Environment Science and Spatial Informatics, China University of Mining and Technology, \\ Xuzhou 221116, China; qjf4209779@163.com (J.-F.Q.); houyule@cumt.edu.cn (Y.-L.H.); \\ mengyu_ge@outlook.com (M.-Y.G.); yyyyunt@163.com (K.W.); liushu@cumt.edu.cn (S.L.); \\ slzhang@cumt.edu.cn (S.-L.Z.); cumt_lig@126.com (G.L.) \\ 2 Low Carbon Energy Institute, China University of Mining and Technology, Xuzhou 221008, China \\ * Correspondence: fchencumt@126.com; Tel.: +86-516-8388-7351 \\ + These authors contributed equally to this work.
}

Academic Editor: Marc A. Rosen

Received: 21 January 2017; Accepted: 13 April 2017; Published: 17 April 2017

\begin{abstract}
Soil organic carbon (SOC) plays an essential role in the early stages of pedogenisis and ecological restoration in reclaimed mine soils. Dynamic changes in the SOC content are essential for assessing the quality of reclaimed mine soils and the effect of ecological restoration. To objectively assess the carbon dynamics of reclaimed soils, we selected the surface $(0-20 \mathrm{~cm})$ soil of farmland under agricultural use (soybean-wheat rotation) from a reclamation chronosequence (R4: 4 years of reclamation, R7: 7 years of reclamation, R10: 10 years of reclamation and R13: 13 years of reclamation) in the Dongtan Mining Area, Shandong Province, China. The adjacent normal, unaffected farmland was used as a control (CK). The results showed that the SOC content gradually increased with the reclamation age until it reached $7.98 \mathrm{~g} \cdot \mathrm{kg}^{-1}$ for R13, which accounted for $76 \%$ of that of the CK. However, the total carbon contents of the reclaimed soils did not significantly differ from and even appeared higher than that of the CK. This is mainly because the inorganic carbon contents of the reclaimed soils ranged from 2.98 to $12.61 \mathrm{~g} \cdot \mathrm{kg}^{-1}$, all of which were significantly higher than the $0.87 \mathrm{~g} \cdot \mathrm{kg}^{-1}$ obtained for the CK. The microbial biomass carbon (MBC) content and the microbial quotient significantly increased with the reclamation age of the soil, and both parameters were markedly higher for R13 than for the CK. The dissolved organic carbon (DOC) content and its ratio to the SOC were significantly higher for R4-R13 than for the CK and DOC/SOC gradually decreased with the reclamation age. Both the reclamation age and the temperature had positive effects on the soil basal respiration (SBR). The SBR rate constantly increased with the reclamation age and was markedly higher at $25^{\circ} \mathrm{C}$ than at $15^{\circ} \mathrm{C}$. The temperature sensitivity $\left(Q_{10}\right)$ of the SBR showed a clearly decreasing trend for the reclamation chronosequence, but its value remained higher for R13 than for the CK (2.37). The metabolic quotient constantly decreased with the reclamation age, which suggests that the survival pressure imposed on soil microbes by the soil environment gradually decreased. These results indicate that it takes a long time for organic carbon to accumulate in reclaimed mine soil and that rational agricultural use contributes to sustained improvement of the quality of reclaimed soil.
\end{abstract}

Keywords: reclaimed mine soils; chronosequence; agricultural use; soil organic carbon; basal respiration 


\section{Introduction}

Soil controls the hydrology, biodiversity, geochemical cycles, and human health and also produce services, goods, and resources for humankind, it is so important that the United Nations put them in a central position related to achieving sustainability of the planet [1-4]. Coal mining is one of the key drivers of land degradation worldwide both in developed nations such as USA, England, Australia, and Spain and emerging economies such as China, India, and Africa [5]. Meanwhile, coal production also is an important economic pillar for many countries especially in emerging economies. Therefore, reclaimed mine soil is particularly crucial to global sustainable development.

China is the largest producer of coal in the world, and its coal production accounts for approximately half of the global production [6-8]. Due to the burial characteristics of coal seams, approximately $92 \%$ of the raw coal is produced by underground mining in China. The resulting land subsidence has emerged as the most prominent problem in coal mining areas [9]. The subsidence problem is particularly serious in coal mining areas in the eastern plains of China, which exhibit typical overlaps of coal mining and agricultural production [9,10]. Land subsidence destroys large areas of arable land and threatens national food security, and water logging in the subsided land area causes the original agro-ecosystem to become an aquatic ecosystem, which seriously affects the regional carbon cycle. Agriculture has become the primary land use pattern of reclaimed land in coal mining areas in the eastern plains of China to ease the pressure on arable land caused by coal mining, restoring the soil quality and maintaining the stability of regional ecosystems [10]. This is different from other large coal producers, such as the USA and India, where open-pit mining is common. In these countries, the land in mining areas is generally reclaimed by forests and vegetation is reconstructed to establish stable ecosystems with high levels of productivity [11-13].

The goal of soil reclamation is to reach a soil quality (including physical, chemical, and biological indicators) that is unaffected or suitable for sustained and stable agricultural use. The soil organic carbon (SOC) as a 'trigger' of the soil's physical structure, nutrient cycling, and biological functions [14], plays an essential role in the early stages of pedogenisis and ecological restoration in reclaimed mine soils $[15,16]$. Research has shown that coal mining may lead to a rapid decrease in the SOC content; the decrease in the SOC pool can reach 70-81\% [17]. Moreover, the storage of surface soil during reclamation can lead to the loss of SOC content. Through reasonable reclamation measures, degraded mine soils can restore large amounts of SOC [18-20] as an important carbon sink. However, the accumulation of SOC is a long-term process. In contrast, indicators of labile organic carbon-such as microbial biomass carbon (MBC) and dissolved organic carbon (DOC) - are more sensitive to the early changes in reclaimed soils. The soil basal respiration (SBR), a sensitive indicator that characterizes microbial activity, can be used to assess soil restoration in degraded ecosystems [21]. Because of the accumulation of SOC and total nitrogen (TN), in reclaimed soils, the physical structure constantly improves and the amounts of nutrients progressively increase, which promotes continuous improvement of the soil's MBC and SBR [14,22]. These properties are not only critical indicators of soil quality but also key processes in the carbon cycle; their changes over time are the basis on which to assess the fertility restoration and carbon sequestration potential of a reclaimed mine soil. Studying the chronosequence is an effective way to assess the trends and rates of change of soil properties $[23,24]$. Studies indicate that the physical, chemical, and biological indicators for reclaimed mine soils constantly improve over time [11,25-27]. For instance, the study of Kumar et al. [28] found that the $\mathrm{MBC}$ and $\mathrm{CO}_{2}$ flux of the soil in the Raniganj Coalfield in eastern India approached the levels of natural forest land 21 years after vegetation reconstruction. Mukhopadhyay et al. [29] reported that the MBC and $\mathrm{CO}_{2}$ flux of the soil in the North Karanpura area of India exceeded the levels of natural forest land after 17 years of reclamation. Moreover, Dangi et al. [30] found that years 5-14 of vegetation reconstruction composed the most important stage in the recovery of the microbial community in a reclaimed mining area in northeastern Wyoming, USA. Despite the positive effect of time on the restoration of reclaimed soil, the time that it takes for reclaimed soil to recover to normal levels varies due to differences in climate conditions, vegetation type, soil texture, and management 
methods. The vegetation type and the land use pattern after reclamation are the most important to soil quality restoration [22]. Existing studies of reclaimed soils have mainly focused on forest and grassland ecosystems; little attention has been paid to reclaimed soils under agricultural cultivation. East China is a major grain-producing area that has taken on an important mission for national food security. Reclamation of the mining areas in East China must consider agricultural use a prerequisite. Therefore, the success of reclaiming these mining areas has great eco-environmental value and social significance.

An increase or decrease in the SOC content of farmland soil is a sign that a specific farmland ecosystem has become a carbon source or sink; additionally, soil respiration is an important short-term factor that characterizes a long-term change in the SOC content. To understand the function and sustainability of reclaimed agro-ecosystems in mining areas, the emphasis is on clarifying the change in the soil indicators after reclamation [26]. The aims of the present study are to assess the change in the total amount of carbon (total carbon (TC), SOC and soil inorganic carbon (SIC)), MBC, DOC, and basal respiration in reclaimed mine soils under soybean-wheat rotation with reclamation time and to monitor the evolution of soil quality and the activity of the soil microbial community in reclaimed mine soils under agricultural use.

\section{Materials and Methods}

\subsection{Study Site}

The study was conducted in the Dongtan Mining Area in Zoucheng $\left(116^{\circ} 46^{\prime} 30^{\prime \prime}-117^{\circ} 28^{\prime} 54^{\prime \prime} \mathrm{E}\right.$, $35^{\circ} 8^{\prime} 12^{\prime \prime}-35^{\circ} 32^{\prime} 54^{\prime \prime} \mathrm{N}$ ), Shandong Province, China (Figure 1). This area has a transitional monsoon climate in the warm temperate zone. The average annual rainfall is $777.1 \mathrm{~mm}$, and the average annual temperature is $14.1^{\circ} \mathrm{C}$. The active accumulated temperature (which refers to the sum of all daily average temperature $\left(\geq 10^{\circ} \mathrm{C}\right)$ in one year and reflects the heat conditions provided by the climate for crops) with an average daily temperature $\geq 10^{\circ} \mathrm{C}$ is $4696.7^{\circ} \mathrm{C}$ and covers 217 days. These conditions satisfy the heat requirements for two years of triple-cropping and one year of double-cropping. The major type of soil is fluvo-aquic soil (CST classification), which is loose and is one of the main agricultural soil in China. The soil texture is silty loam (sand content is $39.47 \%$, silt content is $51.23 \%$, clay content is $9.30 \%$ ) according to the international soil texture classification. Soil organic carbon content is $10.44 \mathrm{~g} \cdot \mathrm{kg}^{-1}$, total nitrogen content is $1.10 \mathrm{~g} \cdot \mathrm{kg}^{-1}$, available nitrogen content is $90.43 \mathrm{mg} \cdot \mathrm{kg}^{-1}$ and available phosphorus content is $23.31 \mathrm{mg} \cdot \mathrm{kg}^{-1}$ (Table 1, Figure 2). The Dongtan Coal Mine, which was put into production in 1989, is the first underground coal mine with a cumulative coal production of greater than 100 million tons in China. Long-term coal mining has resulted in serious surface subsidence, generally with an underground water table of $-1.5 \mathrm{~m}$. Currently, a number of large ponds containing water with a collapse depth of approximately $4-10 \mathrm{~m}$ are present; their formation destroyed large areas of arable land. Since 2000, the coal gangue filling governance model has been promoted in the Dongtan Coal Mine to remediate the ecological environment in the mining area, solve the problem of land occupation by gangue and fulfil the statutory obligation of those who destroy farmland to restore it. The coal gangue site reclamation process was implemented in the coal mining subsidence area from 2001 to 2011. The reclamation process involved filling with coal gangue and covering with surface soil, and the procedure was as follows. Following the surface-underground contrast plan, the surface soil was first stripped and piled in the mining area with no or early-stage subsidence. When the mining subsidence area was stabilized, the water that had formed a pond was discharged, and the debris was removed from the subsidence basin. The compaction and the amount of coal gangue were determined by preliminary experiments. Based on the results, coal gangue was backfilled into the subsidence basin to the designed level and compacted until smooth; the gangue filling layer was approximately 2-4 m thick. Finally, the pre-stripped and stored surface soil was backfilled and compacted until smooth in a layer that was approximately $1.0 \mathrm{~m}$ thick; then, crops were planted on the reclaimed site. By the end of 2011, a total of $140 \mathrm{hm}^{2}$ of land had been reclaimed and $66.7 \mathrm{hm}^{2}$ of arable land had been restored in the Dongtan coal mining subsidence 
areas by means of reclamation with coal gangue filling; the crop rotation system is soybean-wheat rotation (planting soybean in summer and wheat in winter). Because the reclamation project lasted several years, we provide a detailed chronosequence. Except for their reclamation ages, the selected plots were under the same conditions; these included their topography (plain), climate (transitional monsoon climate in the warm temperate zone), parent soil material (river alluvium), crop pattern (soybean-wheat rotation), and methods of tillage (traditional tillage) and fertilization (wheat season fertilizer 180 250 kg.hm ${ }^{-2} \mathrm{~N}, 120 \sim 150 \mathrm{~kg} \cdot \mathrm{hm}^{-2} \mathrm{P}_{2} \mathrm{O}_{5}, 27 \sim 50 \mathrm{~kg} \cdot \mathrm{hm}^{-2} \mathrm{~K}_{2} \mathrm{O}$; soybean season fertilizer $95 \sim 270 \mathrm{~kg} \cdot \mathrm{hm}^{-2} \mathrm{~N}, 40 \sim 120 \mathrm{~kg} \cdot \mathrm{hm}^{-2} \mathrm{P}_{2} \mathrm{O}_{5}, 19 \sim 38 \mathrm{~kg} \cdot \mathrm{hm}^{-2} \mathrm{~K}_{2} \mathrm{O}$; wheat straw returning).
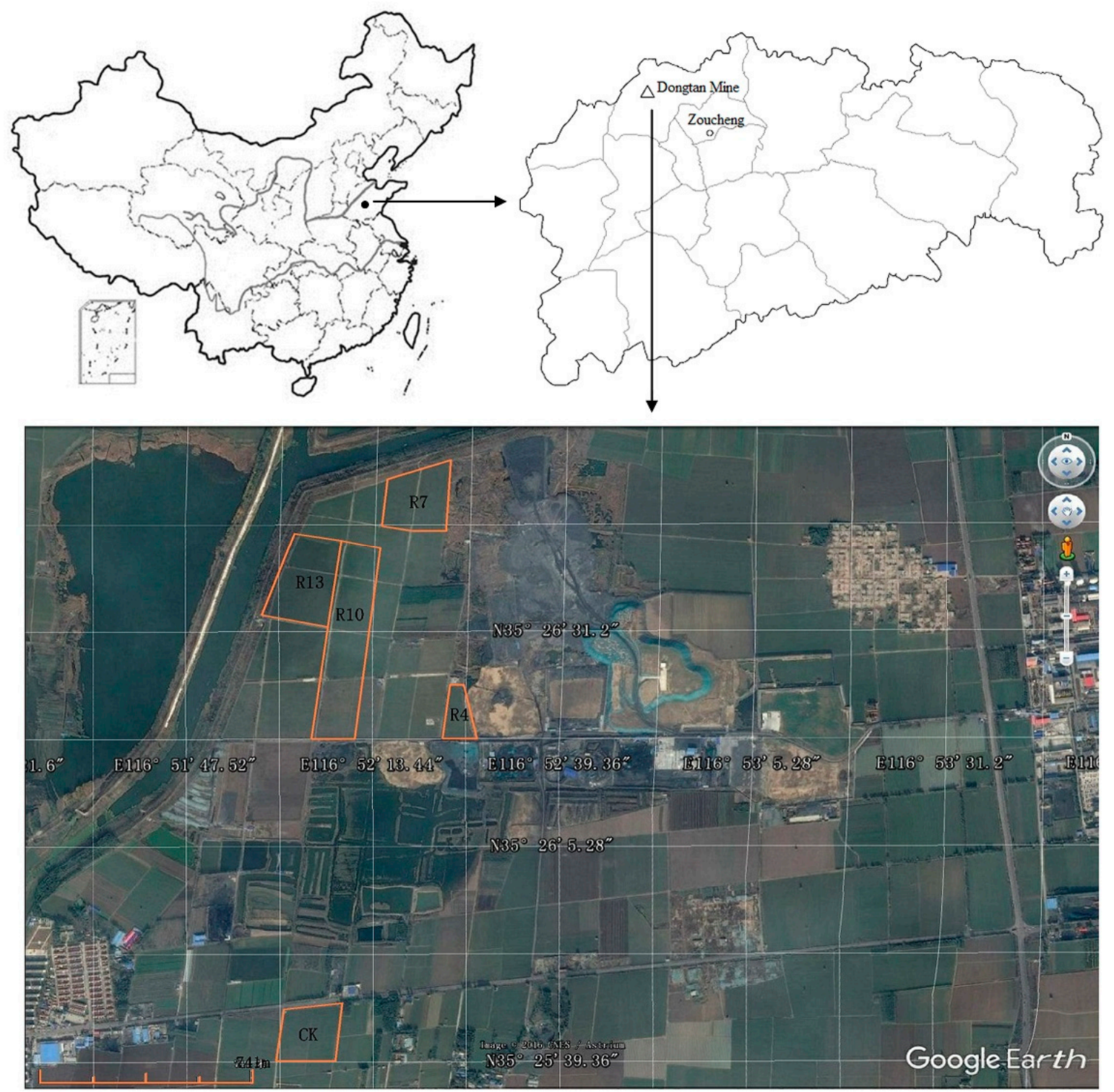

Figure 1. Geographic locations of the experimental sites. R4 = 4 years of reclamation; R7 = 7 years of reclamation; $\mathrm{R} 10$ = 10 years of reclamation; $\mathrm{R} 13$ = 13 years of reclamation; $\mathrm{CK}=$ control site. 

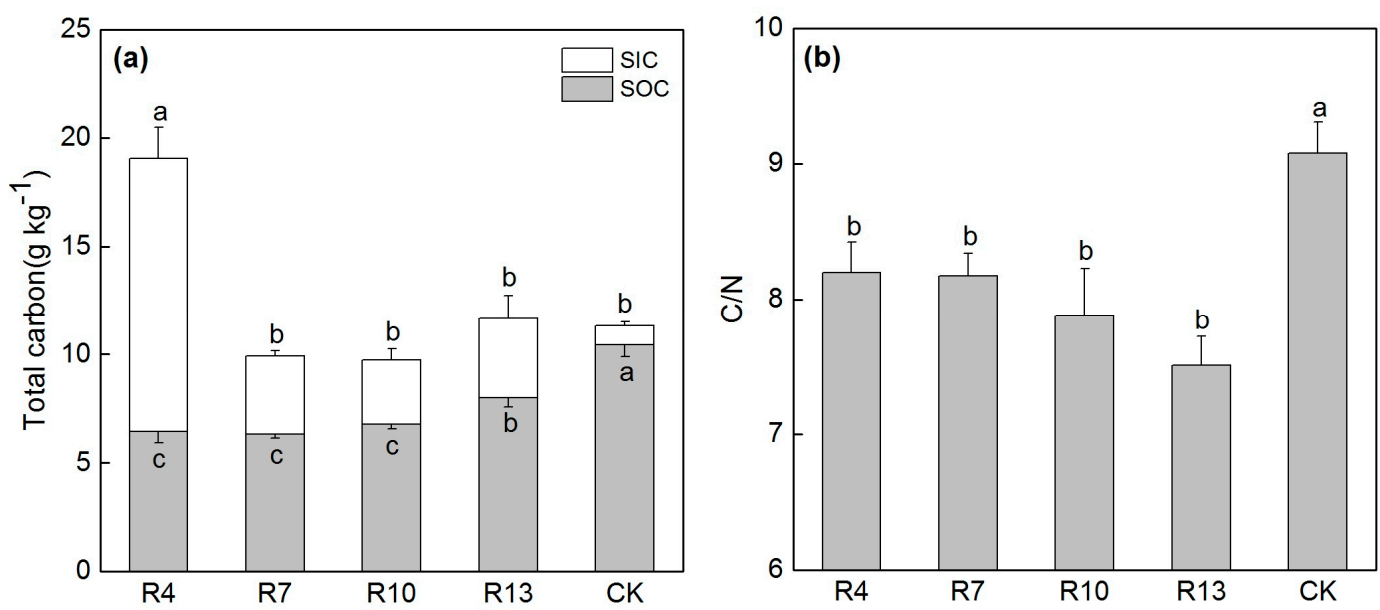

Figure 2. Change in the soil's (a) total carbon and (b) $\mathrm{C} / \mathrm{N}$ ratio with the reclamation age. Error bars represent the standard error; different lowercase letters indicate significant differences at $p<0.05$ according to Duncan's multiple range tests.

Table 1. Changes in the basic physicochemical properties of soils with different reclamation ages.

\begin{tabular}{cccccc}
\hline & $\mathbf{R 4}^{\mathbf{1}}$ & $\mathbf{R 7}$ & $\mathbf{R 1 0}$ & $\mathbf{R} 13$ & CK \\
\hline $\mathrm{pH}$ & $8.33 \pm 0.07 \mathrm{a}^{2}$ & $8.65 \pm 0.03 \mathrm{a}$ & $8.67 \pm 0.07 \mathrm{a}$ & $8.39 \pm 0.09 \mathrm{a}$ & $6.64 \pm 0.23 \mathrm{~b}$ \\
$\mathrm{EC}\left(\mu \mathrm{S} \cdot \mathrm{cm}^{-1}\right)$ & $156.83 \pm 15.67 \mathrm{bc}$ & $222.63 \pm 31.63 \mathrm{ab}$ & $282.17 \pm 30.97 \mathrm{a}$ & $230.17 \pm 19.45 \mathrm{a}$ & $111.28 \pm 6.58 \mathrm{c}$ \\
$\mathrm{TN}\left(\mathrm{g} \cdot \mathrm{kg}^{-1}\right)$ & $0.79 \pm 0.06 \mathrm{~b}$ & $0.78 \pm 0.02 \mathrm{~b}$ & $0.86 \pm 0.02 \mathrm{~b}$ & $1.06 \pm 0.03 \mathrm{a}$ & $1.10 \pm 0.03 \mathrm{a}$ \\
$\mathrm{AN}\left(\mathrm{mg} \cdot \mathrm{kg}^{-1}\right)$ & $40.97 \pm 6.01 \mathrm{c}$ & $51.40 \pm 1.47 \mathrm{c}$ & $64.45 \pm 4.89 \mathrm{~b}$ & $63.22 \pm 2.80 \mathrm{~b}$ & $90.43 \pm 3.25 \mathrm{a}$ \\
$\mathrm{AP}\left(\mathrm{mg} \cdot \mathrm{kg}^{-1}\right)$ & $4.49 \pm 0.84 \mathrm{~b}$ & $8.38 \pm 1.08 \mathrm{~b}$ & $8.80 \pm 1.22 \mathrm{~b}$ & $12.44 \pm 4.86 \mathrm{~b}$ & $23.31 \pm 3.30 \mathrm{a}$ \\
\hline
\end{tabular}

${ }^{1} \mathrm{R} 4=4$ years of reclamation; R7 $=7$ years of reclamation; R10 = 10 years of reclamation; R13 = 13 years of reclamation; $\mathrm{CK}=$ control farmland. ${ }^{2}$ Data are mean $\pm \mathrm{SE}$. Different lowercase letters in the same line indicate significant differences with age of reclamation at $p<0.05$ according to Duncan's multiple range tests.

\subsection{Collection of Mine Soil Samples}

Using the "space-for-time" method, a chronosequence was formed using soils with 4 years (R4, $\left.2.0 \mathrm{hm}^{2}\right), 7$ years $\left(\mathrm{R} 7,4.7 \mathrm{hm}^{2}\right), 10$ years $\left(\mathrm{R} 10,7.5 \mathrm{hm}^{2}\right)$, and 13 years $\left(\mathrm{R} 13,6.3 \mathrm{hm}^{2}\right)$ of reclamation (Figure 1). Additionally, a farmland soil that was unaffected by mining activities was selected as a control $\left(\mathrm{CK}, 5.0 \mathrm{hm}^{2}\right)$ in the area adjacent to the reclaimed site. Soil samples were collected in October 2014. Six sampling points per plot in an S-shaped pattern were selected using a multi-point sampling method. At each sampling point, three cores of soil at $0-20 \mathrm{~cm}$ were collected using a stainless steel sampler with an inner diameter of $3.5 \mathrm{~cm}$ and a length of $50 \mathrm{~cm}$. The three cores were mixed to obtain a composite soil sample. After collection, impurities—such as plant roots and gravel-were removed from the soil samples. Each sample was thoroughly mixed and evenly divided into two portions. One portion was air-dried at room temperature and passed through a 2-mm sieve before its basic physicochemical properties were analyzed; the other portion was sealed in a Ziploc bag and stored in a refrigerator at $4{ }^{\circ} \mathrm{C}$ before its $\mathrm{MBC}, \mathrm{DOC}$, and SBR were analyzed.

\subsection{Soil Analyses}

Soil $\mathrm{pH}$ (soil/water $=2.5: 1)$ was measured using a digital $\mathrm{pH}$ meter (PHS-3E, Youke, Shanghai, China); soil electrical conductivity (EC; soil/water $=5: 1$ ) was measured using a conductivity meter (SX713, Sanxin, Shanghai, China). Soil organic carbon (SOC) was analyzed by potassium dichromate oxidation-ferrous sulphate titrimetry method [31]. Soil available nitrogen (AN) was measured using the alkali N-proliferation method, and its available phosphorus (AP) was measured using Olsen method [32]. Soil total carbon (TC) and total nitrogen (TN) contents were measured using a FlashEA 1112 Series NC Analyzer (Thermo Fisher Scientific, Waltham, MA, USA). The soil inorganic carbon 
(SIC) content was calculated by subtracting the SOC content from the TC content. Soil microbial biomass carbon (MBC) was determined using the chloroform fumigation-extraction method [33] and calculated as $\mathrm{MBC}=\mathrm{E}_{\mathrm{c}} / \mathrm{K}_{\mathrm{c}}$, where $\mathrm{K}_{\mathrm{c}}=0.45$. To determine the soil dissolved organic carbon (DOC) content, $(20 \pm 0.01) \mathrm{g}$ (dry weight) of the fresh sample was placed into a conical flask containing $100 \mathrm{~mL}$ of deionized water. The suspension was oscillated at room temperature for $30 \mathrm{~min}$ and then, centrifuged at $9000 \mathrm{r} / \mathrm{min}$ for $10 \mathrm{~min}$. The supernatant was passed through a $0.45 \mu \mathrm{m}$ membrane filter, and the organic carbon concentration of the liquid extract was measured using a TOC analyzer (Multi NC3100, Analytik Jena, Jena, Germany).

To measure SBR, a $2 \mathrm{~mm}$-sieved moist soil was used. After plant litter and roots were removed, the maximum field capacity of the soil was measured. Determination steps of maximum soil field capacity: (1) Fill the air-dried soil sample into a cutting ring, make the soil surface smooth and higher $(1 \sim 2 \mathrm{~mm})$ than the cutting ring. Then cover the soil surface with a piece of filter paper and place it cutting ring on the table. (2) Put the cutting ring which is filled with undisturbed sample (field acquisition) on a flat container. Add water to the container and until it is just below (1 2 $\mathrm{mm})$ the top of cutting ring, then soak it for $24 \mathrm{~h}$. (3) Remove the bottom cover of cutting ring which is filled with undisturbed sample and water. Put this cutting ring on the top of cutting ring which is filled with air-dried soil and press them together with a brick $(2 \mathrm{~kg})$. (4) After $8 \mathrm{~h}$, take out $20 \sim 30 \mathrm{~g}$ soil from the upper cutting ring and measure its wet weight and dry weight. Then calculate the soil moisture content also is the maximum soil field capacity. Then, place an equivalent soil sample with a dry weight of $30.0 \mathrm{~g}$ into a $350-\mathrm{mL}$ culture flask. Adjust the moisture to $60 \%$ of the maximum field capacity of the soil to be cultured. Incubated the prepared soil in a low-temperature thermostat bath (DC-0530, Shanghai Bilon Instrument Co., Shanghai, China). Two temperatures (15.0 and $\left.25.0^{\circ} \mathrm{C}\right)$ were set. The time was recorded after the bath temperature increased to a pre-set temperature, and the sample was stabilized for $2 \mathrm{~h}$ under aeration conditions. Then, the flasks were sealed, and at the beginning and end of the sealing process, a syringe was used to collect a sample containing $5.0 \mathrm{~mL}$ of gas from each flask. The $\mathrm{CO}_{2}$ in the gas sample was analysed using a gas chromatograph (Agilent 6890, Agilent Corp., Palo Alto, CA, USA). Immediately after the first gas sample was collected, the flask was supplemented with $\mathrm{CO}_{2}$-free gas to avoid the impact of negative pressure on the soil respiration. The respiration rate during this period was calculated as

$$
S B R=\frac{M \times P \times T_{0} \times \Delta C \times V}{22.4 \times P_{0} \times T \times \Delta t \times m} \times 24,
$$

where $S B R$ is the soil basal respiration rate $\left(\mathrm{mg} \cdot \mathrm{CO}_{2}-\mathrm{C} \cdot \mathrm{kg}^{-1} \cdot \mathrm{d}^{-1}\right) ; \mathrm{M}$ is the molar mass of $\mathrm{CO}_{2}-\mathrm{C}$ $\left(\mathrm{g} \cdot \mathrm{mol}^{-1}\right) ; 22.4$ is the molar volume of gas $\left(\mathrm{L} \cdot \mathrm{mol}^{-1}\right)$ in the standard state (temperature, $273 \mathrm{~K}$; pressure, $101.3 \mathrm{kPa}) ; T_{0}$ and $P_{0}$ are the absolute temperature $(\mathrm{K})$ and pressure $(\mathrm{kPa})$ of air, respectively, in the standard state (temperature, $273 \mathrm{~K}$; pressure, $101.3 \mathrm{kPa}) ; P$ is the pressure $(\mathrm{kPa})$ during sampling; $T$ is the absolute temperature (K) during sampling; $\Delta C / \Delta t$ is the change in the $\mathrm{CO}_{2}$ concentration (ppm) within the flask over time (h) during the observation period; $V$ is the headspace volume in the flask (L); and $\mathrm{m}$ is the dry weight of the incubated soil (g).

The metabolic quotient $\left(q \mathrm{CO}_{2}\right)$ is the ratio of the SBR to the MBC [22]. The temperature sensitivity $\left(Q_{10}\right)$ of soil respiration was calculated as follows [34]:

$$
Q_{10}=\left(\frac{R_{2}}{R_{1}}\right)^{\left(\frac{10}{T_{2}-T_{1}}\right)}
$$

where $R_{1}$ and $R_{2}$ are the SBR rates at temperatures $T_{1}$ and $T_{2}$, respectively $\left(T_{1}<T_{2}\right)$.

\subsection{Statistical Analysis}

A one-way analysis of variance (ANOVA) and Duncan's test were performed using SPSS 21.0 (SPSS Inc., Chicago, IL, USA) for the analysis of variance and the test of significant difference 
$(\alpha=0.05)$ of the soil property indicators for the samples with different reclamation ages and the control. The correlations were analyzed using a Pearson correlation analysis.

\section{Results}

\subsection{Basic Physicochemical Properties}

Compared with the control farmland $(\mathrm{CK}, 6.64)$, the reclaimed soils were alkaline (R4-R10, 8.33-8.67) and had significantly higher $\mathrm{pH}$ values. The $\mathrm{pH}$ initially increased and then, decreased with the reclamation chronosequence, but no significant differences between the different reclamation ages were found (Table 1). Similar to the $\mathrm{pH}$, the soil EC increased from R4 to R10 $\left(156.83-282.17 \mu \mathrm{S} \cdot \mathrm{cm}^{-1}\right)$. The EC for R13 was relatively low but significantly higher than the value for the CK $\left(111.28 \mu \mathrm{S} \cdot \mathrm{cm}^{-1}\right.$, Table 1).

The soil TN content increased constantly with the reclamation age. However, the increase in the TN content was slow from R4 to R10, which had significantly lower values than the CK $\left(1.10 \mathrm{~g} \cdot \mathrm{kg}^{-1}\right)$. A marked increase occurred between R10 and R13, and the TN content for R13 reached $96.36 \%$ of that of the CK. The AN and AP contents of the soil both constantly increased with the reclamation chronosequence, but the values were significantly lower for R13 than for the CK (Table 1), i.e., they were $69.91 \%$ and $53.37 \%$ of the value for the CK, respectively.

\subsection{TC, SIC, and SOC}

Except for the significantly higher TC content of R4, no significant difference was found among the other reclamation ages, and the results were generally consistent with those of the CK. The TC content of R3 was slightly higher than that of the CK (Figure 2a). Similar to the TC content, the SIC content did not significantly differ with the restoration age except in R4; overall, it was higher than that of the CK (Figure 2a). Additionally, Figure 2a shows that in the reclaimed mine soils, the percentage of the TC made up by the SIC gradually decreased with the reclamation age, i.e., $66.19 \%$ (R4), $36.23 \%$ (R7), $29.33 \%$ (R10), and 31.50\% (R13), which were all higher than the CK's value of $8 \%$.

The trend of the SOC content was consistent with that of the TN content. Both the parameters increased with the reclamation age, but the change from R4 to R10 was not significant. Despite a substantial increase at a reclamation age between those of R10 and R13, the SOC content of R13 $\left(7.98 \mathrm{~g} \cdot \mathrm{kg}^{-1}\right)$ was significantly lower than that of the CK $\left(10.44 \mathrm{~g} \cdot \mathrm{kg}^{-1}\right.$, Figure 2a). The carbon-nitrogen $(\mathrm{C} / \mathrm{N})$ ratio of the reclaimed soils gradually decreased as the reclamation age increased; however, no significant difference was found, and the $\mathrm{C} / \mathrm{N}$ ratio was always lower than that of the $\mathrm{CK}$ (Figure $2 \mathrm{~b}$ ).

\section{3. $M B C$ and $D O C$}

The MBC content increased constantly with the reclamation age and showed significant differences (Figure 3a). In particular, the MBC content of R4 was significantly lower than that of the CK; the MBC content reached $239.83 \mathrm{mg} \cdot \mathrm{kg}^{-1}$ for R10, that is, $100.48 \%$ of that of the $\mathrm{CK}$, and the MBC content of R13 (346.32 $\mathrm{mg} \cdot \mathrm{kg}^{-1}$ ) was significantly higher than that of the CK. The DOC content initially decreased and then increased with the reclamation age; it ranged from 81.02 to $86.99 \mathrm{mg} \cdot \mathrm{kg}^{-1}$. Although no significant difference was found for the different reclamation ages, the DOC contents of the reclaimed soils were, overall, significantly higher than that of the CK, $64.06 \mathrm{mg} \cdot \mathrm{kg}^{-1}$ (Figure 3b).

The reclamation age showed markedly different effects with respect to the microbial quotient (MBC/SOC, MQ) and the DOC/SOC (Figure 3c,d). The trend in the soil MQ was consistent with that of the soil MBC. Both these parameters gradually increased with the reclamation age and varied significantly. The MQ of R4 $(1.89 \%)$ was close to that of the CK $(2.27 \%)$, whereas the MQs of R7-R13 were significantly higher than that of the CK (Figure 3c). Conversely, the DOC/SOC ratio decreased with the reclamation age, but overall, the DOC/SOC ratios of the reclaimed mine soils were significantly higher than that of the CK. Except for the significant difference between R4 and R13, no significant differences were found in the DOC/SOC ratios for the remaining reclamation ages (Figure 3d). 

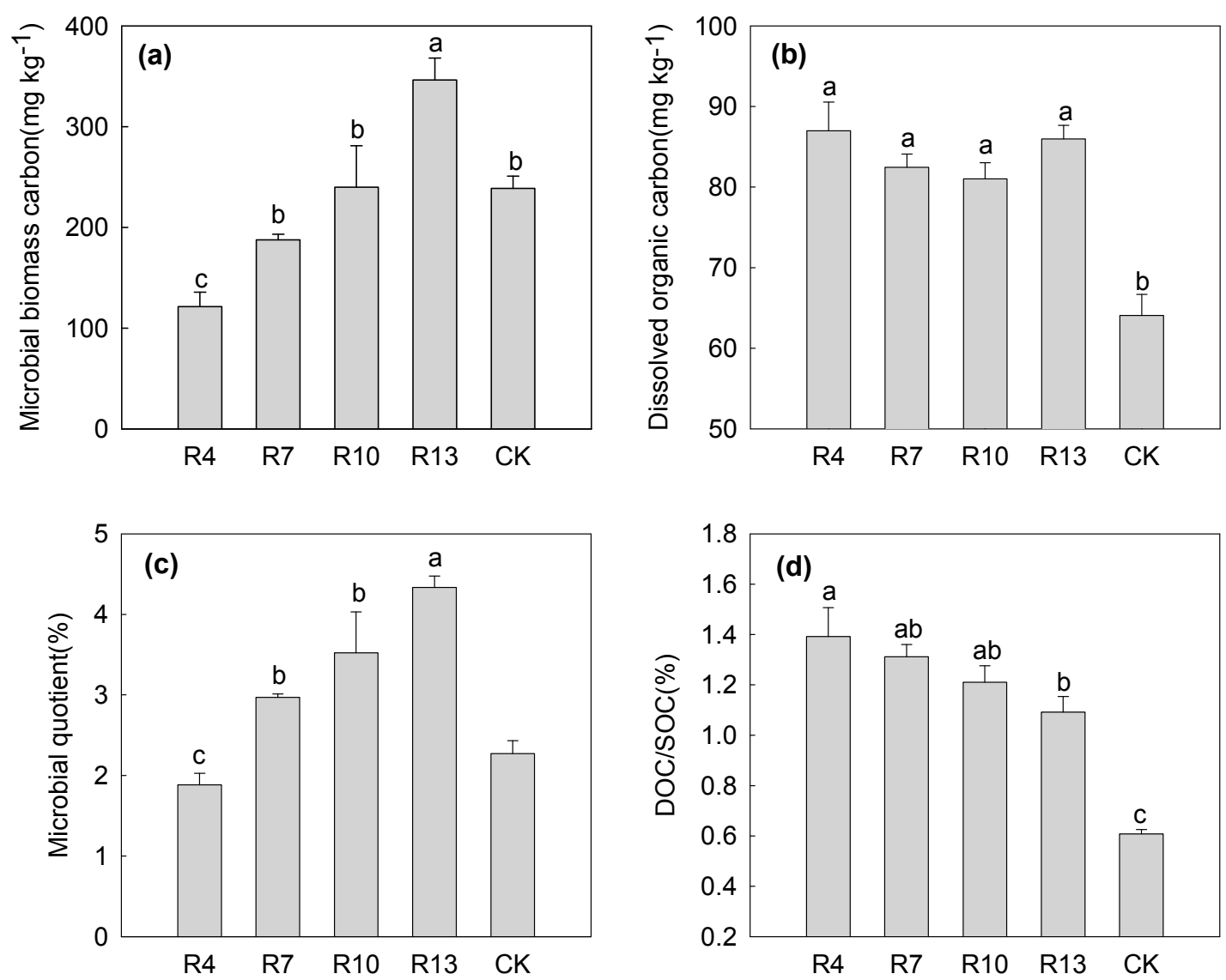

Figure 3. Change in the soil's (a) MBC, (b) DOC, (c) MQ, and (d) DOC/SOC with the reclamation age. Error bars represent the standard error; different lowercase letters indicate significant differences at $p<$ 0.05 according to Duncan's multiple range tests.

\section{4. $\mathrm{SBR}$ and $q \mathrm{CO}_{2}$}

At $15^{\circ} \mathrm{C}$, the SBR rates of the reclaimed soils gradually increased with the reclamation age; its values were $0.88 \mathrm{mg} \cdot \mathrm{CO}_{2}-\mathrm{C} \cdot \mathrm{kg}^{-1} \cdot \mathrm{d}^{-1}$ for $\mathrm{R} 4,1.14 \mathrm{mg} \cdot \mathrm{CO}_{2}-\mathrm{C} \cdot \mathrm{kg}^{-1} \cdot \mathrm{d}^{-1}$ for $\mathrm{R} 7$, $2.26 \mathrm{mg} \cdot \mathrm{CO}_{2}-\mathrm{C} \cdot \mathrm{kg}^{-1} \cdot \mathrm{d}^{-1}$ for R10, and $2.80 \mathrm{mg} \cdot \mathrm{CO}_{2}-\mathrm{C} \cdot \mathrm{kg}^{-1} \cdot \mathrm{d}^{-1}$ for R13. In terms of the SBR, R4 and R7 were significantly lower than the CK (i.e., $27.98 \%$ and $36.33 \%$ of the value for the CK, respectively); R10 and R13 showed no significant difference compared with the CK $(71.81 \%$ and $88.86 \%$ of the value for the $\mathrm{CK}$, respectively) (Figure 4a). At $25{ }^{\circ} \mathrm{C}$, the SBR rates of the reclaimed soils varied between 9.25 and $10.24 \mathrm{mg} \cdot \mathrm{CO}_{2}-\mathrm{C} \cdot \mathrm{kg}^{-1} \cdot \mathrm{d}^{-1}$. The SBR rate slightly, but not significantly, increased with the reclamation age. Compared with the value for the CK $\left(7.38 \mathrm{mg} \cdot \mathrm{CO}_{2}-\mathrm{C} \cdot \mathrm{kg}^{-1} \cdot \mathrm{d}^{-1}\right)$, the SBR rates for R4-R13 were significantly higher (Figure 4a). Additionally, Figure 4a shows that the SBR rate was markedly affected by temperature and significantly higher at $25^{\circ} \mathrm{C}$ than at $15{ }^{\circ} \mathrm{C}$. The temperature sensitivity $\left(Q_{10}\right)$ of the SBR rate for different reclamation ages was 12.04 (R4), 8.26 (R7), 4.66 (R10), and 3.97 (R13). The $Q_{10}$ significantly decreased with the chronosequence of reclamation but remained higher for R13 than for the CK (2.37, Figure 4c).

At $15{ }^{\circ} \mathrm{C}$, the soil $q \mathrm{CO}_{2}$ did not significantly change with the reclamation age. In terms of the $q \mathrm{CO}_{2}, \mathrm{R} 10$ and R13 were slightly higher than R4 and R7 but were, overall, lower than the $\mathrm{CK}$ (Figure $4 \mathrm{~b}$ ). At $25{ }^{\circ} \mathrm{C}$, the soil $q \mathrm{CO}_{2}$ significantly decreased as the reclamation age increased, and the maximum was found for $\mathrm{R} 4\left(0.084 \mathrm{mg} \cdot \mathrm{CO}_{2}-\mathrm{C} \cdot \mathrm{mg}^{-1} \cdot \mathrm{MBC} \cdot \mathrm{d}^{-1}\right)$. The $q \mathrm{CO}_{2}$ decreased to $0.030 \mathrm{mg} \cdot \mathrm{CO}_{2}-\mathrm{C} \cdot \mathrm{mg}^{-1} \cdot \mathrm{MBC} \cdot \mathrm{d}^{-1}$ for R13, which was generally consistent with the value for $\mathrm{CK}$ $\left(0.028 \mathrm{mg} \cdot \mathrm{CO}_{2}-\mathrm{C} \cdot \mathrm{mg}^{-1} \cdot \mathrm{MBC} \cdot \mathrm{d}^{-1}\right)$ (Figure $\left.4 \mathrm{~b}\right)$. 

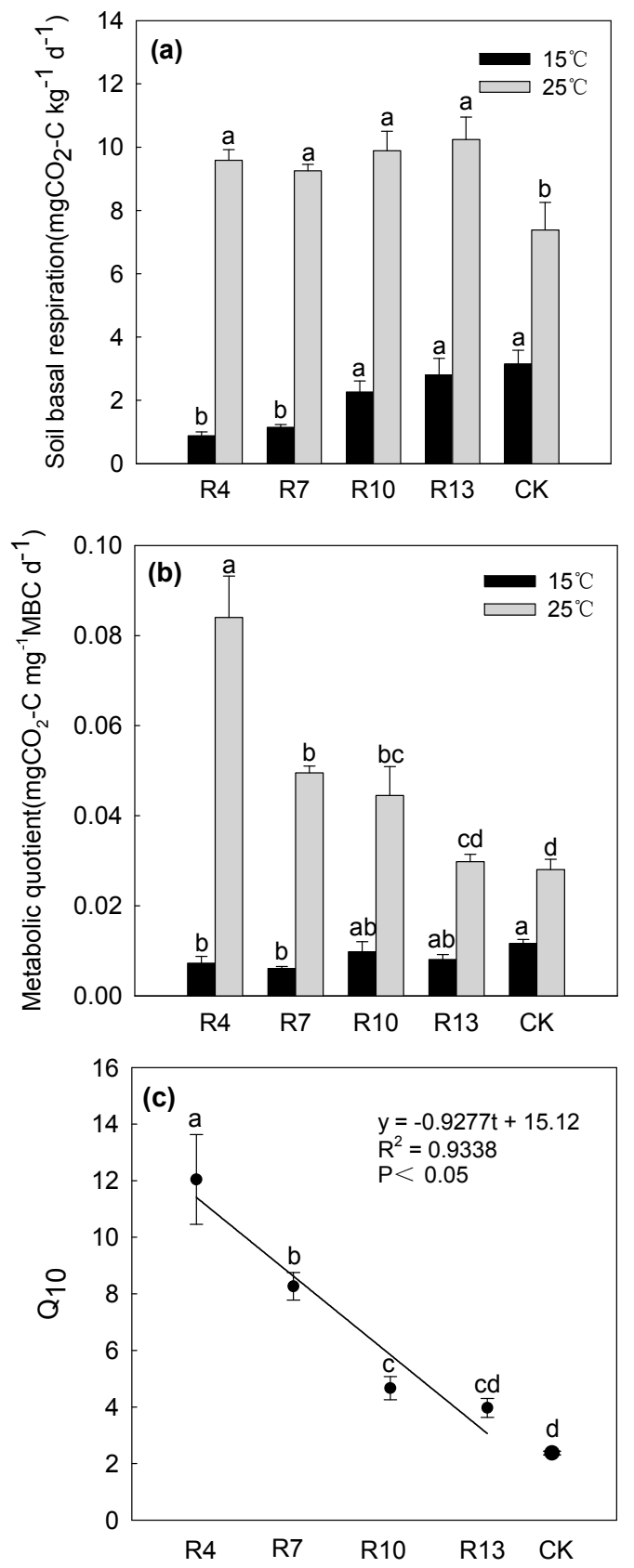

Figure 4. Change in the (a) SBR rate, (b) $q \mathrm{CO}_{2}$, and (c) $Q_{10}$ with the reclamation age. Error bars represent the standard error; different lowercase letters indicate significant differences at $p<0.05$ according to Duncan's multiple range tests.

\subsection{Correlations between the Soil Carbon Content, the SBR Rate, and Physicochemical Properties}

Correlation analysis (Table 2) showed that the MBC, TN, and AN of the reclaimed soils was strongly positively correlated with the SOC $(p<0.01)$. The MQ and SBR was significantly positively correlated with the SOC $(p<0.05)$. Moreover, the $q \mathrm{CO}_{2}, \mathrm{pH}$ and SIC was negatively correlated with the SOC $(p<0.05)$. Additionally, a significant negative correlation was found between the DOC and the $\mathrm{pH}(p<0.05)$. The SBR rate showed highly significant positive correlations with the MBC and TN contents and with the MQ, AN, and AP contents $(p<0.01)$. The $q \mathrm{CO}_{2}$ was negatively correlated with the SOC, MBC, and TN contents and with the MQ, the SBR rate contents and the EC at the significant $(p<0.05)$ or highly significant level $(p<0.01)$. 
Table 2. Correlations between the soil carbon content, the SBR rate, and physicochemical properties.

\begin{tabular}{|c|c|c|c|c|c|c|c|c|c|}
\hline & SOC & MBC & DOC & MQ & DOC/SOC & $\begin{array}{c}\text { SBR } \\
\left(15^{\circ} \mathrm{C}\right)\end{array}$ & $\begin{array}{c}\text { SBR } \\
\left(25^{\circ} \mathrm{C}\right)\end{array}$ & $\begin{array}{c}q \mathrm{CO}_{2} \\
\left(15^{\circ} \mathrm{C}\right)\end{array}$ & $\begin{array}{c}q \mathrm{CO}_{2} \\
\left(25^{\circ} \mathrm{C}\right)\end{array}$ \\
\hline SOC & 1 & & & & & & & & \\
\hline MBC & $0.737 * *$ & 1 & & & & & & & \\
\hline DOC & 0.242 & 0.020 & 1 & & & & & & \\
\hline MQ & $0.502 *$ & 0.948 ** & -0.076 & 1 & & & & & \\
\hline $\mathrm{DOC} / \mathrm{SOC}$ & $-0.889 * *$ & $-0.680 * *$ & 0.153 & $-0.504 *$ & 1 & & & & \\
\hline $\operatorname{SBR}\left(15^{\circ} \mathrm{C}\right)$ & $0.482 *$ & $0.687^{* *}$ & 0.011 & $0.629^{* *}$ & -0.425 & 1 & & & \\
\hline $\operatorname{SBR}\left(25^{\circ} \mathrm{C}\right)$ & 0.384 & 0.305 & 0.175 & 0.211 & -0.317 & $0.773^{* *}$ & 1 & & \\
\hline$q \mathrm{CO}_{2}\left(15^{\circ} \mathrm{C}\right)$ & -0.016 & -0.030 & 0.068 & -0.040 & 0.053 & $0.650 * *$ & $0.675^{* *}$ & 1 & \\
\hline$q \mathrm{CO}_{2}\left(25^{\circ} \mathrm{C}\right)$ & $-0.568^{* *}$ & $-0.849 * *$ & 0.050 & $-0.871^{* *}$ & $0.601 * *$ & $-0.442 *$ & -0.019 & 0.254 & 1 \\
\hline $\mathrm{pH}$ & $-0.412 *$ & -0.146 & $-0.449 *$ & 0.054 & 0.131 & -0.089 & -0.213 & 0.011 & -0.155 \\
\hline EC & 0.261 & 0.512 * & 0.053 & $0.570 * *$ & -0.302 & $0.564^{* *}$ & 0.440 * & 0.312 & -0.443 * \\
\hline $\mathrm{TN}$ & $0.904^{* *}$ & $0.846^{* *}$ & 0.332 & $0.689^{* *}$ & $-0.771^{* *}$ & $0.705^{* *}$ & $0.480 *$ & 0.301 & $-0.661^{* *}$ \\
\hline $\mathrm{TC}$ & -0.259 & $-0.452 *$ & 0.294 & $-0.524 *$ & $0.477^{*}$ & -0.356 & -0.099 & -0.176 & $0.657^{* *}$ \\
\hline AN & $0.525^{* *}$ & $0.599 * *$ & 0.051 & $0.590 * *$ & $-0.561 * *$ & $0.670 * *$ & 0.393 & 0.433 & $-0.641^{* *}$ \\
\hline $\mathrm{AP}$ & $0.467 *$ & $0.510 *$ & 0.147 & $0.449 *$ & -0.412 & $0.658^{* *}$ & $0.537^{*}$ & 0.161 & -0.368 \\
\hline SIC & $-0.468^{*}$ & $-0.591^{* *}$ & 0.208 & $-0.600^{* *}$ & $0.644^{* *}$ & $-0.470 *$ & -0.184 & -0.177 & 0.733 ** \\
\hline
\end{tabular}

${ }^{* *}$ Significant correlation at the 0.01 level (two-tailed). ${ }^{*}$ Significant correlation at the 0.05 level (two-tailed). 


\section{Discussion}

Time is a major factor in pedogenisis and a critical driver of all soil processes [24]. In the present study, the SOC content was found to gradually increase with the reclamation age (Figure 2a). This indicates that in similar pedogenetic conditions, time has a positive effect on the evolution of the SOC in reclaimed soils [25]. Several chronosequence studies $[19,26,28,35]$ have shown that SOC constantly accumulates in reclaimed soils over time, which shows great potential for carbon sequestration. The carbon sequestration potential of reclaimed soils depends mainly on the biomass they contain and its return to the soil; moreover, the carbon sequestration potential is affected by the mechanism protecting the soil carbon [36]. During agricultural use of reclaimed mine soils, crop roots and litter continuously enter the soil, and large amounts of organic manure and chemical fertilizers are applied, which causes the soil carbon input to increase with the reclamation age [37]. Additionally, plant litter and root exudates form soil humus via decomposition, transformation, and synthesis, which promotes the formation of soil aggregates and thereby provides physical protection of the organic carbon [38], which is conducive to the accumulation of SOC. In the present study, despite the constant increase in the SOC content with the reclamation age, the growth rate was very slow, and the SOC content of R13 was only 1.24 that of R4. Zhao et al. [35] found that the SOC content increased rapidly when forest and grassland ecosystems were reconstructed in an open-pit mine area; after 13 years of reclamation, the value reached 3.1 times what it was after four years. This may be because during the reconstruction of forest and grassland ecosystems, the aboveground vegetation biomass and litter constantly increase and undergo humification, which can effectively improve the soil texture and promote the rapid accumulation of SOC. In contrast, although large amounts of organic manure and chemical fertilizer are used in agriculture, the vast majority of aboveground crops are removed every year and mechanical ploughing further destroys soil aggregates; to a certain extent, these processes decrease the rate of SOC accumulation. It has been reported as the reclamation age increases, the rate of SOC accumulation in soils reclaimed by forest and grassland ecosystems decreases $[17,39,40]$. The SOC content gradually increases and tends to stabilize; ultimately, the carbon pool reaches a new equilibrium state [18]. However, the rate of SOC accumulation during the early stages was found to be rather low in reclaimed soil used for agriculture. We consider that it may be more difficult for the SOC stock of reclaimed soil being used for agriculture to return to its original unaffected level than that of a forest-grassland composite ecosystem. Jacinthe et al. [37] investigated the carbon pool in reclaimed soils under conventional tillage in the mining area of southwestern Indiana, USA. They believed that it would take 50 years to reach a new equilibrium state and that the SOC stock after equilibrium accounted for approximately $71 \%$ of the original state, which further verifies our hypothesis. In the present study, the change in the SOC of the reclaimed farmland soil has reached $76 \%$ of the value for the original landscape. Whether the SOC stock can be further restored and how long it will take are pending in-depth studies.

Although we found significantly lower SOC contents in the reclaimed soils than in the control farmland, the TC content did not significantly differ from and was even higher than it was in the control (Figure 2a). This is mainly because the SIC contents of the reclaimed soils ranged from 2.98 to $12.61 \mathrm{~g} \cdot \mathrm{kg}^{-1}$ (i.e., $29.33-66.19 \%$ of the TC content), which was significantly higher than the value of $0.87 \mathrm{~g} \cdot \mathrm{kg}^{-1}$ for the control farmland ( $8 \%$ of the TC content). This is similar to the result of Stahl et al. [41]; however, Chaudhuri et al. [24] reported that the SIC content accounted for less than $4 \%$ of the TC content of reclaimed soils in West Virginia, USA. The difference in the SIC content between the reclaimed and control soils is mainly due to the characteristics of the carbon content of the overlying soil and is therefore mainly controlled by the soil's parent material rather than mining and reclamation processes [42].

A soil's $\mathrm{C} / \mathrm{N}$ ratio is an important indicator that characterises whether microbial growth is subject to carbon or nitrogen limitation in reclaimed soils, and the optimal range for the $\mathrm{C} / \mathrm{N}$ ratio to meet the soil's functional requirements is 8-12 [20]. Numerous studies have shown that nitrogen is the main factor limiting vegetation reconstruction in degraded mining areas; the large amounts of soil 
nutrients absorbed and the low amounts of organic residues returned to the soil result in low nitrogen contents in reclaimed forest soils [43-45]. In reclaimed soils used for agriculture, annual ploughing may lead to the mineralization of organic carbon and thereby slow down the accumulation of SOC [20]. Moreover, the application of nitrogen fertilizer and the nitrogen fixation of legumes can enhance the accumulation of nitrogen $[18,20,46]$. The synergistic effect of these two factors leads to a decrease in the $\mathrm{C} / \mathrm{N}$ ratio of a soil. In the present study, the $\mathrm{C} / \mathrm{N}$ ratios of the reclaimed soils were significantly lower than that of the control farmland and gradually decreased as the reclamation age increased (Figure $2 b$ ). This indicates that the amount of carbon supplied is the main factor limiting microbial growth in the soil.

$\mathrm{MBC}$ is an important source of nutrients for plants. Following reclamation in mining areas, the accumulation of labile carbon can promote a rapid increase in the soil MBC content and the associated microbial activity [29,47]. In the present study, the soil MBC content increased from 121.36 to $346.32 \mathrm{mg} \cdot \mathrm{kg}^{-1}$ over the 4 to 13 years of reclamation and, after 13 years of reclamation, was markedly higher than that of control farmland (Figure 3a). This result is consistent with most existing studies $[26,29,48]$ and supports the view that " $5-14$ years of reclamation is the most important stage for restoration of soil microbial communities" proposed by Dangi et al. [30] in a study of soil microbial community restoration in mining areas. This indicates that soil microbial communities are also gradually restored during reclamation. However, it usually takes more than 20 years to restore a soil's microbial biomass to the level of the original landscape in the semi-arid mining areas in Wyoming, USA [49]. The correlation analysis revealed a highly significant positive correlation between the MBC and the SOC contents $(r=0.737, p<0.01)$, which is in agreement with the results of Adeli et al. [26] and Ingram et al. [50]. This suggests that organic matter is the main energy source for soil microorganisms; the organic carbon added to reclaimed soils during agricultural activities is rapidly utilized by microbial communities, which contributes to the rapid increase in the soil's MBC content and the restoration of a damaged ecosystem.

The soil DOC is the carbon component that is best for microbial growth [51]. The DOC content is generally no greater than $2 \%$ of the total SOC; however, compared with the relatively stable components of humus, the soil DOC has a higher degradation rate [52,53], and its dynamic changes can reflect the stability of the SOC. In the present study, the soil DOC content of reclaimed farmland was significantly higher than that of control farmland and decreased with reclamation age. Because DOC is leached downward by water and immobilized by subsurface mineral soil [54], the DOC content of subsurface soil is usually higher than that of surface soil. However, during reclamation, the soil layer is disturbed, and part of the subsurface soil is ploughed to the surface; therefore, the DOC content of reclaimed farmland surface soil is markedly higher than that of control farmland soil. Subsequently, the number of soil microbes grows and soil respiration is enhanced during agricultural use, which results in a gradual decrease in the soil DOC content [55]. Additionally, the $\mathrm{pH}$ of the soil is an important factor that affects the change in its DOC content. At a high $\mathrm{pH}$, the acid moiety of DOC is prone to neutralization reactions with other substances, such as calcium and magnesium compounds, which decreases the DOC content of the soil [56]. In the current study, we found a significant negative correlation between the soil's $\mathrm{pH}$ and DOC content $(r=-0.449, p<0.05)$. This indicates that an increase in the $\mathrm{pH}$ contributes to the decrease of the DOC contents of the reclaimed soils.

The MQ serves as a sensitive indicator of the quality of the soil carbon pool and can be used to infer the availability of carbon. Compared with the MBC content, the MQ can better reflect the influence of agricultural use on the carbon in reclaimed soils. It has been noted that the higher the $\mathrm{MQ}$ is, the more carbon accumulates in the soil; additionally, the MQ changes with the structure and number of microbial populations restored, which slows the conversion from non-labile to labile organic carbon and eventually, increases the SOC content [57]. In the present study, the MQ markedly increased with the reclamation age and exhibited a significant positive correlation with the SOC content $(r=0.502, p<0.05)$ (Figure 3c, Table 2). This shows that the availability of soil carbon and the carbon sequestration capacity of soil were enhanced and that SOC increasingly accumulated 
during agricultural use. A higher DOC/SOC ratio indicates that organic matter can be more easily decomposed by microbes. The DOC/SOC ratio is often used as a good indicator for the turnover of the biologically active organic carbon pool of a soil. Therefore, the decrease in the DOC/SOC ratio with the reclamation age observed in this study means that the turnover rate of the soil's biologically active organic carbon pool decreased, which corroborates the decrease in the rate of conversion from non-labile to labile organic carbon in reclaimed soils with the reclamation age, as indicated by the MQ.

Soil respiration is an important biological indicator that characterizes a soil's quality and fertility. In particular, the SBR rate reflects the soil's microbial activity, the SOC content and the amount of decomposition and is an important early indicator used to assess the restoration status of degraded mine soils [22,58]. In the present study, the SBR rate showed a markedly increasing trend with the reclamation age. The same result has been reported in the studies of Wiseman et al. [59] and Mukhopadhyay et al. [29] on a chronosequence of reclaimed mine soils. During the agricultural use of reclaimed soils, on the one hand, the amount of labile organic carbon (the substrate of microbes) in the soil rapidly increases; on the other hand, the soil's physical properties, including its structure, water retention and aeration, improve. All these aspects contribute to a significant increase in the SBR rate. The correlation analysis revealed significant positive correlations between the SBR rate and the SOC content and between the SBR rate and the MBC content (Table 2), which further demonstrates that an increase in the labile organic carbon is one of the factors that leads to an increase in the SBR. In addition to the reclamation age, temperature is an important factor that affects soil respiration [60,61]. The SBR was markedly higher at $25{ }^{\circ} \mathrm{C}$ than it was at $15{ }^{\circ} \mathrm{C}$ for different reclamation ages (Figure 4a). This indicates that the increase in temperature (from $15{ }^{\circ} \mathrm{C}$ to $25^{\circ} \mathrm{C}$ ) significantly improved the microbial activity and the rate of substrate utilization, which contributed to SBR. The temperature sensitivity of soil respiration depends on the activity of the SOC, namely, the supply capacity of substrates [62-64]. In the present study, the temperature sensitivity $\left(Q_{10}\right)$ decreased with the reclamation age. This may be because, in the early stage of reclamation, the number and activity of soil microbial communities are relatively low, whereas the labile organic carbon (DOC) content is relatively high and the supply of substrate is sufficient, which result in a high $Q_{10}$; as the reclamation age increases, the number and activity of soil microbial communities increase while the labile organic carbon (DOC) content decreases and the substrate supply is relatively insufficient, which results in a decreased $Q_{10}$. Moreover, $Q_{10}$ was substantially higher for the reclaimed soils in this study than for the control farmland. The reasons $Q_{10}$ values were so high may include: (1) Bacteria amounts were predominant (more than 95\%) in reclaimed soil [65]. Because of the small size, strong metabolism, and large contact area with soil, the microbial community dominated by bacteria generally has higher temperature sensitivity [66]. (2) Coal gangue contains a large amount of carbon. During reclamation, this carbon source is released under suitable environmental conditions and adds to the $\mathrm{CO}_{2}$ content of the overlying soil, which affects the temperature sensitivity of the soil's respiration [67].

The $q \mathrm{CO}_{2}$ reflects the substrate utilisation efficiency of soil microbes; a low $q \mathrm{CO}_{2}$ indicates high efficiency. As the reclamation age increases, the survival pressure on soil microbes posed by the soil environment decreases; therefore, the $q \mathrm{CO}_{2}$ decreased gradually. This is in agreement with the conclusion of the analysis of the $\mathrm{C} / \mathrm{N}$ ratio. Many studies have shown that the $q \mathrm{CO}_{2}$ gradually decreased as the SOC content or the MBC increased $[22,39,68]$. According to the theory of ecology, when soil microbes are subjected to environmental stress or disturbance, the energy needed to maintain their growth increases; therefore, the $q \mathrm{CO}_{2}$ increases. When the substrate carbon uptake is unchanged, this inevitably leads to a decrease in the MBC used for microbial growth, and the MQ decreases [69]. A combination of a soil's MQ and $q \mathrm{CO}_{2}$ reflects environmental changes well and provides an important ecological and physiological index for assessing the quality and health of the soil [69]. In reclaimed soils, microbes may be subjected to stress due to the destruction caused by coal mining and the disturbance caused by the reclamation project; therefore, the $q \mathrm{CO}_{2}$ is relatively high and the MQ is relatively low. During agricultural use, the stress on the soil microbes gradually disappears as the disturbance disappears and the eco-environment is restored; therefore, the $q \mathrm{CO}_{2}$ decreases and the MQ increases. 
The lack of a substrate may limit the growth of microbial communities [70]. A change in a soil's $q \mathrm{CO}_{2}$ may also reflect a change in microbial community structure [71,72]. Because fungi utilize substrates more efficiently (i.e., have a lower $q \mathrm{CO}_{2}$ ) than bacteria [73], the decrease in the $q \mathrm{CO}_{2}$ observed in the reclaimed mine soils may also be due to a decrease in the fungi/bacteria ratio. Therefore, further studies are needed to obtain an in-depth understanding of the mechanism underlying the change in the $\mathrm{MQ}$ and the $q \mathrm{CO}_{2}$ of reclaimed mine soils.

\section{Conclusions}

Time had a positive effect on the accumulation of SOC in reclaimed farmland in mining areas. Meanwhile, the soybean-wheat rotation, NPK fertilizer and wheat straw returning also played an important role. The SOC and TN contents both gradually increased with the reclamation age, but the relatively high $\mathrm{pH}$ and $\mathrm{EC}$ of the reclaimed soils needed further improvement. The total carbon content of the reclaimed soils did not significantly differ from and was even higher than that of the control farmland, particularly the SIC content. Moreover, the $\mathrm{C} / \mathrm{N}$ ratio of the reclaimed soils was significantly lower than that of the control farmland and gradually decreased as the reclamation age increased. The supply of organic carbon became a major factor limiting the growth of soil microbes. The soil MBC content and MQ constantly increased, whereas the DOC/SOC ratio decreased as the reclamation age increased. The number and activity of soil microbes continued to increase, and the conversion from non-labile to labile organic carbon slowed down, which enhanced the capacity for accumulating SOC. Both the reclamation age and the temperature had positive effects on the SBR rate. The SBR rate increased constantly with the reclamation age and was significantly higher at $25^{\circ} \mathrm{C}$ than at $15{ }^{\circ} \mathrm{C}$. The temperature sensitivity $\left(Q_{10}\right)$ of the SBR rate markedly decreased with the reclamation chronosequence but, after 13 years of reclamation, was still higher than that of the control farmland. As the reclamation age increased, the stress of the soil environment on the soil microbes gradually decreased. In-depth studies are needed to further elucidate the mechanism of change in the MQ and $q \mathrm{CO}_{2}$, two important eco-physiological indicators for evaluating the quality and health of reclaimed mine soils.

Acknowledgments: This study was supported by a Chinese National Natural Science Foundation grant (51474214) and the National Key Technology Support Program of China (2015BAD06B02).

Author Contributions: Fu Chen, Gang Li, and Jun-Feng Qu conceived and designed the experiments; Kun Wang, Yu-Le Hou, Shu Liu, and Meng-Yu Ge performed the experiments; Yu-Le Hou and Shao-Liang Zhang analyzed the data; Jun-Feng Qu and Yu-Le Hou wrote the paper; all authors read and approved the final manuscript.

Conflicts of Interest: The authors declare no conflict of interest.

\section{References}

1. Brevik, E.C.; Cerdà, A.; Mataix-Solera, J.; Pereg, L.; Quinton, J.N.; Six, J.; van Oost, K. The interdisciplinary nature of SOIL. Soil 2015, 1, 117-129. [CrossRef]

2. Mol, G.; Keesstra, S. Soil science in a changing world. Curr. Opin. Environ. Sustain. 2012, 4, 473-477. [CrossRef]

3. Keesstra, S.D.; Geissen, V.; Mosse, K.; Piiranen, S.; Scudiero, E.; Leistra, M.; van Schaik, L. Soil as a filter for groundwater quality. Curr. Opin. Environ. Sustain. 2012, 4, 507-516. [CrossRef]

4. Keesstra, S.D.; Bouma, J.; Wallinga, J.; Tittonell, P.; Smith, P.; Cerdà, A.; Montanarella, L.; Quinton, J.N.; Pachepsky, Y.; van der Putten, W.H.; et al. The significance of soils and soil science towards realization of the United Nations Sustainable Development Goals. Soil 2016, 2, 111-128. [CrossRef]

5. Lechner, A.M.; Baumgartl, T.; Matthew, P.; Glenn, V. The Impact of Underground Longwall Mining on Prime Agricultural Land: A Review and Research Agenda. Land Degrad. Dev. 2016, 27, 1650-1663. [CrossRef]

6. Enerdata Global Energy Statistical Yearbook. Available online: https://yearbook.enerdata.net/\#coal-andlignite-production.html (accessed on 15 August 2016).

7. $\mathrm{Hu}, \mathrm{Z} . ; \mathrm{Fu}, \mathrm{Y}$; $\mathrm{Xiao}_{\mathrm{iao}} \mathrm{W} . ; \mathrm{Zhao}, \mathrm{Y}$; Wei, T. Ecological restoration plan for abandoned underground coal mine site in Eastern China. Int. J. Min. Reclam. Environ. 2015, 29, 316-330. [CrossRef] 
8. Wang, P.; Hu, Z.; Yost, R.S.; Shao, F.; Liu, J.; Li, X. Assessment of chemical properties of reclaimed subsidence land by the integrated technology using Yellow River sediment in Jining, China. Environ. Earth Sci. 2016, 75, 1-15. [CrossRef]

9. Hu, Z.; Xiao, W. Optimization of concurrent mining and reclamation plans for single coal seam: A case study in northern Anhui, China. Environ. Earth Sci. 2012, 68, 1247-1254. [CrossRef]

10. Xiao, W.; Hu, Z.; Chugh, Y.P.; Zhao, Y. Dynamic subsidence simulation and topsoil removal strategy in high groundwater table and underground coal mining area: A case study in Shandong Province. Int. J. Min. Reclam. Environ. 2013, 28, 250-263. [CrossRef]

11. Chodak, M.; Pietrzykowski, M.; Niklińska, M. Development of microbial properties in a chronosequence of sandy mine soils. Appl. Soil Ecol. 2009, 41, 259-268. [CrossRef]

12. Maiti, S.K. Ecorestoration of the Coalmine Degraded Lands; Springer: New York, NY, USA, 2013.

13. Ahirwal, J.; Maiti, S.K. Assessment of soil properties of different land uses generated due to surface coal mining activities in tropical Sal (Shorea robusta) forest, India. Catena 2016, 140, 155-163. [CrossRef]

14. Moreno-De Las Heras, M. Development of soil physical structure and biological functionality in mining spoils affected by soil erosion in a Mediterranean-Continental environment. Geoderma 2009, 149, 249-256. [CrossRef]

15. Bodlák, L.; Křováková, K.; Kobesová, M.; Brom, J.; Št’astný, J.; Pecharová, E. SOC content-An appropriate tool for evaluating the soil quality in a reclaimed post-mining landscape. Ecol. Eng. 2012, 43, 53-59. [CrossRef]

16. Pietrzykowski, M.; Daniels, W.L. Estimation of carbon sequestration by pine (Pinus sylvestris L.) ecosystems developed on reforested post-mining sites in Poland on differing mine soil substrates. Ecol. Eng. 2014, 73, 209-218. [CrossRef]

17. Akala, V.A.; Lal, R. Soil organic carbon pools and sequestration rates in reclaimed minesoils in Ohio. J. Environ. Qual. 2001, 30, 2098-2104. [CrossRef] [PubMed]

18. Ussiri, D.A.N.; Lal, R. Carbon sequestration in reclaimed minesoils. Crit. Rev. Plant Sci. 2005, 24, 151-165. [CrossRef]

19. Akala, V.A.; Lal, R. Potential of mine land reclamation for soil organic carbon sequestration in Ohio. Land Degrad. Dev. 2000, 11, 289-297. [CrossRef]

20. Shrestha, R.K.; Lal, R. Soil carbon and nitrogen in 28-year-old land uses in reclaimed coal mine soils of Ohio. J. Environ. Qual. 2007, 36, 1775-1783. [CrossRef] [PubMed]

21. Helingerová, M.; Frouz, J.; Šantrůčková, H. Microbial activity in reclaimed and unreclaimed post-mining sites near Sokolov (Czech Republic). Ecol. Eng. 2010, 36, 768-776. [CrossRef]

22. Šourková, M.; Frouz, J.; Fettweis, U.; Bens, O.; Hüttl, R.F.; Šantrưčková, H. Soil development and properties of microbial biomass succession in reclaimed post mining sites near Sokolov (Czech Republic) and near Cottbus (Germany). Geoderma 2005, 129, 73-80. [CrossRef]

23. Brantley, S.L. Understanding soil time. Science 2008, 321, 1454-1455. [CrossRef] [PubMed]

24. Chaudhuri, S.; McDonald, L.M.; Pena-Yewtukhiw, E.M.; Skousen, J.; Roy, M. Chemically stabilized soil organic carbon fractions in a reclaimed minesoil chronosequence: Implications for soil carbon sequestration. Environ. Earth Sci. 2013, 70, 1689-1698. [CrossRef]

25. Chaudhuri, S.; Pena-Yewtukhiw, E.M.; McDonald, L.M.; Skousen, J.; Sperow, M. Early C sequestration rate changes for reclaimed minesoils. Soil Sci. 2012, 177, 443-450. [CrossRef]

26. Adeli, A.; McLaughlin, M.R.; Brooks, J.P.; Read, J.J.; Willers, J.L.; Lang, D.J.; McGrew, R. Age chronosequence effects on restoration quality of reclaimed coal mine soils in Mississippi agroecosystems. Soil Sci. 2013, 178, 335-343. [CrossRef]

27. Gasch, C.K.; Huzurbazar, S.V.; Wick, A.F.; Stahl, P.D. Assessing impacts of crested wheatgrass and native species establishment on soil characteristics in reclaimed land using Bayesian posterior predictive distributions. Land Degrad. Dev. 2016, 27, 521-531. [CrossRef]

28. Kumar, S.; Maiti, S.K.; Chaudhuri, S. Soil development in 2-21 years old coalmine reclaimed spoil with trees: A case study from Sonepur-Bazari opencast project, Raniganj Coalfield, India. Ecol. Eng. 2015, 84, 311-324. [CrossRef]

29. Mukhopadhyay, S.; Maiti, S.K.; Masto, R.E. Development of mine soil quality index (MSQI) for evaluation of reclamation success: A chronosequence study. Ecol. Eng. 2014, 71, 10-20. [CrossRef]

30. Dangi, S.R.; Stahl, P.D.; Wick, A.F.; Ingram, L.J.; Buyer, J.S. Soil microbial community recovery in reclaimed soils on a surface coal mine site. Soil Sci. Soc. Am. J. 2012, 76, 915-924. [CrossRef] 
31. Yeomans, J.; Bremmer, J.M. A rapid and precise method four routine determination of organic carbon in soil. Commun. Soil Sci. Plant 1989, 19, 1467-1476. [CrossRef]

32. Olsen, S.R.; Sommers, L.E. Phosphorus. In Methods of Soil Analysis; Miller, A.L., Keeney, D.R., Eds.; American Society of Agronomy: Madison, WI, USA, 1982; pp. 403-427.

33. Vance, E.D.; Brookes, P.C.; Jenkinson, D.S. An extraction method for measuring soil microbial biomass C. Soil Biol. Biochem. 1987, 19, 703-707. [CrossRef]

34. Hochachka, P.W.; Somero, G.N. Biochemical Adaptations; Princeton University Press: Princeton, NJ, USA, 1984.

35. Zhao, Z.; Shahrour, I.; Bai, Z.; Fan, W.; Feng, L.; Li, H. Soils development in opencast coal mine spoils reclaimed for 1-13 years in the West-Northern Loess Plateau of China. Eur. J. Soil Biol. 2013, 55, 40-46. [CrossRef]

36. Shrestha, R.K.; Lal, R. Ecosystem carbon budgeting and soil carbon sequestration in reclaimed mine soil. Environ. Int. 2006, 32, 781-796. [CrossRef] [PubMed]

37. Jacinthe, P.-A.; Lal, R. Tillage effects on carbon sequestration and microbial biomass in reclaimed farmland soils of southwestern Indiana. Soil Sci. Soc. Am. J. 2009, 73, 605-613. [CrossRef]

38. Wick, A.F.; Ingram, L.J.; Stahl, P.D. Aggregate and organic matter dynamics in reclaimed soils as indicated by stable carbon isotopes. Soil Biol. Biochem. 2009, 41, 201-209. [CrossRef]

39. Insam, H.; Domsch, K.H. Relationship between soil organic carbon and microbial biomass on chronosequences of reclamation sites. Microb. Ecol. 1988, 15, 177-188. [CrossRef] [PubMed]

40. Shrestha, R.K.; Lal, R. Carbon and nitrogen pools in reclaimed land under forest and pasture ecosystems in Ohio, USA. Geoderma 2010, 157, 196-205. [CrossRef]

41. Stahl, P.D.; Wick, A.F.; Ganjegunte, G.; Norton, U.; Ingram, L.J. Redevelopment of soil carbon pools on reclaimed surface mine lands. In Revitalizing the Environment: Proven Solutions and Innovative Approaches; Barnhisel, R.I., Ed.; ASMR: Billings, MT, USA, 2009; pp. 1348-1370.

42. Das, R.; Maiti, S.K. Importance of carbon fractionation for the estimation of carbon sequestration in reclaimed coalmine soils-A case study from Jharia coalfields, Jharkhand, India. Ecol. Eng. 2016, 90, 135-140. [CrossRef]

43. Rodrigue, J.A.; Burger, J.A. Forest soil productivity of mined land in the Midwestern and eastern coalfield regions. Soil Sci. Soc. Am. J. 2004, 68, 833-844. [CrossRef]

44. Chatterjee, A.; Lal, R.; Shrestha, R.K.; Ussiri, D.A.N. Soil carbon pools of reclaimed minesoils under grass and forest landuses. Land Degrad. Dev. 2009, 20, 300-307. [CrossRef]

45. Keskin, T.; Makineci, E. Some soil properties on coal mine spoils reclaimed with black locust (Robinia pceudoacacia L.) and umbrella pine (Pinus pinea L.) in Agacli-Istanbul. Environ. Monit. Assess. 2009, 159, 407-414. [CrossRef] [PubMed]

46. Boldt-Burisch, K.; Anne Naeth, M.; Schneider, B.U.; Huttl, R.F. Linkage between root systems of three pioneer plant species and soil nitrogen during early reclamation of a mine site in Lusatia, Germany. Restor. Ecol. 2015, 23, 357-365. [CrossRef]

47. Mukhopadhyay, S.; Masto, R.E.; Yadav, A.; George, J.; Ram, L.C.; Shukla, S.P. Soil quality index for evaluation of reclaimed coal mine spoil. Sci. Total Environ. 2016, 542, 540-550. [CrossRef] [PubMed]

48. Banning, N.C.; Grant, C.D.; Jones, D.L.; Murphy, D.V. Recovery of soil organic matter, organic matter turnover and nitrogen cycling in a post-mining forest rehabilitation chronosequence. Soil Biol. Biochem. 2008, 40, 2021-2031. [CrossRef]

49. Anderson, J.D.; Ingram, L.J.; Stahl, P.D. Influence of reclamation management practices on microbial biomass carbon and soil organic carbon accumulation in semiarid mined lands of Wyoming. Appl. Soil Ecol. 2008, 40, 387-397. [CrossRef]

50. Ingram, L.J.; Schuman, G.E.; Stahl, P.D.; Spackman, L.K. Microbial respiration and organic carbon indicate nutrient cycling recovery in reclaimed soils. Soil Sci. Soc. Am. J. 2005, 69, 1737-1745. [CrossRef]

51. Asensio, V.; Vega, F.A.; Covelo, E.F. Effect of soil reclamation process on soil C fractions. Chemosphere 2014, 95, 511-518. [CrossRef] [PubMed]

52. Andreasson, F.; Bergkvist, B.; Bååth, E. Bioavailability of DOC in leachates, soil matrix solutions and soil water extracts from beech forest floors. Soil Biol. Biochem. 2009, 41, 1652-1658. [CrossRef]

53. Bu, X.; Ding, J.; Wang, L.; Yu, X.; Huang, W.; Ruan, H. Biodegradation and chemical characteristics of hot-water extractable organic matter from soils under four different vegetation types in the Wuyi Mountains, southeastern China. Eur. J. Soil Biol. 2011, 47, 102-107. [CrossRef] 
54. Sanderman, J.; Amundson, R. A comparative study of dissolved organic carbon transport and stabilization in California forest and grassland soils. Biogeochemistry 2008, 89, 309-327. [CrossRef]

55. Cookson, W.R.; Osman, M.; Marschner, P.; Abaye, D.A.; Clark, I.; Murphy, D.V.; Stockdale, E.A.; Watson, C.A. Controls on soil nitrogen cycling and microbial community composition across land use and incubation temperature. Soil Biol. Biochem. 2007, 39, 744-756. [CrossRef]

56. Wu, J.M.; Xi, M.; Kong, F.L.; Li, Y.; Zhang, Q.L. Review of researches on the factors influencing the dynamics of dissolved organic carbon in soils. Geol. Rev. 2013, 59, 953-961.

57. Singh, J.S.; Raghubanshi, R.S.; Singh, R.S.; Srivastava, S.C. Microbial biomass acts as a source of plant nutrient in dry tropical forest and savanna. Nature 1989, 338, 499-500. [CrossRef]

58. Chodak, M.; Niklińska, M. Effect of texture and tree species on microbial properties of mine soils. Appl. Soil Ecol. 2010, 46, 268-275. [CrossRef]

59. Wiseman, P.E.; Seiler, J.R. Soil $\mathrm{CO}_{2}$ efflux across four age classes of plantation loblolly pine (Pinus taeda L.) on the Virginia Piedmont. For. Ecol. Manag. 2004, 192, 297-311. [CrossRef]

60. Subke, J.A.; Bahn, M. On the 'temperature sensitivity' of soil respiration: Can we use the immeasurable to predict the unknown? Soil Biol. Biochem. 2010, 42, 1653-1656. [CrossRef] [PubMed]

61. Wang, Y.; Bölter, M.; Chang, Q.; Duttmann, R.; Scheltz, A.; Petersen, J.F.; Wang, Z. Driving factors of temporal variation in agricultural soil respiration. Acta. Agric. Scand. Sect. B Soil Plant Sci. 2015, 65, 589-604. [CrossRef]

62. Gershenson, A.; Bader, N.E.; Cheng, W. Effects of substrate availability on the temperature sensitivity of soil organic matter decomposition. Glob. Chang. Biol. 2009, 15, 176-183. [CrossRef]

63. Liu, H. Thermal response of soil microbial respiration is positively associated with labile carbon content and soil microbial activity. Geoderma 2013, 193, 275-281. [CrossRef]

64. Bujalský, L.; Kaneda, S.; Dvorščík, P.; Frouz, J. In situ soil respiration at reclaimed and unreclaimed post-mining sites: Responses to temperature and reclamation treatment. Ecol. Eng. 2014, 68, 53-59. [CrossRef]

65. Fan, W.; Bai, Z.; Li, H.; Qiao, J.; Xu, J. Effects of different vegetation restoration patterns and reclamation years on microbes in reclaimed soil. Trans. Chin. Soc. Agric. Eng. 2011, 27, 330-336.

66. Biasi, C.; Rusalimova, O.; Meyer, H.; Kaiser, C.; Wanek, W.; Barsukov, P.; Junger, H.; Richter, A. Temperature-dependent shift from labile to recalcitrant carbon sources of arctic heterotrophs. Rapid Commun. Mass Spectrom. RCM 2005, 19, 1401-1408. [CrossRef] [PubMed]

67. Chen, X.Y.; Wang, F.; Yan, J.P.; Liu, Y.; Tan, H.Y.; Zhou, Y.Z. Effect of coversoil thickness on diurnal variation characteristics of reclaimed soil respiration in coal mining areas. J. Chin. Univ. Min. Technol. 2016, 45, 163-169.

68. Šantr, H.; SiraŠicraba, M. On the relationship between specific respiration activity and microbial biomass in soils. Soil Biol. Biochem. 1991, 23, 525-532. [CrossRef]

69. Anderson, T.-H. Microbial eco-physiological indicators to asses soil quality. Agric. Ecosyst. Environ. 2003, 98, 285-293. [CrossRef]

70. Mastrogianni, A.; Papatheodorou, E.M.; Monokrousos, N.; Menkissoglu-Spiroudi, U.; Stamou, G.P. Reclamation of lignite mine areas with Triticum aestivum: The dynamics of soil functions and microbial communities. Appl. Soil Ecol. 2014, 80, 51-59. [CrossRef]

71. Tripathi, S.; Kumari, S.; Chakraborty, A.; Gupta, A.; Chakrabarti, K.; Bandyapadhyay, B.K. Microbial biomass and its activities in salt-affected coastal soils. Biol. Fertil. Soils 2005, 42, 273-277. [CrossRef]

72. Wong, V.N.L.; Dalal, R.C.; Greene, R.S.B. Salinity and sodicity effects on respiration and microbial biomass of soil. Biol. Fertil. Soils 2008, 44, 943-953. [CrossRef]

73. Blagodatskaya, E.V.; Anderson, T.-H. Interactive effects of $\mathrm{pH}$ and substrate quality on the fungal-to-bacterial ratio and $\mathrm{qCO}_{2}$ of microbial communities in forest soils. Soil Biol. Biochem. 1998, 30, 1269-1274. [CrossRef]

(c) 2017 by the authors. Licensee MDPI, Basel, Switzerland. This article is an open access article distributed under the terms and conditions of the Creative Commons Attribution (CC BY) license (http:/ / creativecommons.org/licenses/by/4.0/). 